\title{
Trgovački centri u Zagrebu
}

\author{
Martina Jakovčić, Dubravka Spevec
}

\begin{abstract}
U radu je prikazan razmještaj trgovačkih centara u Zagrebu i analizirana su njihova gravitacijska područja. Na temelju rezultata anketa provedenih u King Crossu, Mercatoneu i Mercatoru prikazuje se razvoj pojedinih funkcija trgovačkih centara te se ukazuje na značajnu dominaciju trgovačkih funkcija u odnosu na socijalne funkcije.

Ključne riječi: maloprodajni oblici kupovine, socijalne funkcije, trgovački centri, trgovačke funkcije, Zagreb
\end{abstract}

\section{Shopping Centres in Zagreb}

The article deals with spatial distribution of shopping centres in Zagreb and their catchments areas. The analysis of the shopping centres' functions has been made on the basis of results obtained by the surveys done in King Cross, Mercatone and Mercator. It revealed domination of retail over social functions.

Key words: retail, retail functions, shopping centres, social functions, Zagreb

\section{UVOD}

Trgovina je jedna od najvitalnijih i najvažnijih gradskih funkcija te je kao takva imala važnu ulogu u postanku, razvoju i oblikovanju mnogih gradova. Tijekom vremena trgovina je doživjela mnoge promjene; mijenjala se veličina prodavaonica, njihova lokacija, raspored i način prodaje, a sve u skladu s promjenama u prostornom razmještaju stanovništva i povećanjem standarda, kupovne moći i mobilnosti (Standl 1998).

Trgovina je jedna od najdinamičnijih ljudskih djelatnosti te je kao takva objekt istraživanja brojnih struka. Promjene u prostoru i društvu te utjecaj trgovine na te promjene na različite su načine objekti istraživanja geografa, psihologa, sociologa, ekonomista itd. Zbog toga se može reći da je trgovina danas više od gospodarske djelatnosti.

Istraživanja o maloprodaji i njenoj prostornoj organizaciji započela su, na području geografije u okviru urbane geografije, '30-ih godina 20. stoljeća, a nakon 1950. ta se istraživanja intenziviraju. 
Tijekom 1990-ih godina, u okviru "nove geografije maloprodaje"" posebna se pažnja posvećuje istraživanju trgovačkih centara. U ranijim radovima naglasak je bio na lokaciji trgovačkih centara no u posljednje vrijeme raste broj radova koji se bave njihovim funkcijama te strategijama razvoja. Također sve više se razvija i istraživanje ostalih oblika trgovine kao što su kupovina putem kataloga, virtualna kupovina i sl. $^{2}$ (Crewe 2000.)

Trgovački centar je grupa maloprodajnih i drugih komercijalnih objekata koja je planirana i razvijana kao jedinstvena cjelina te ima jedinstvenu upravu. Svi trgovački centri imaju osigurano veliko parkiralište. ${ }^{3}$ Definicije trgovačkih centara, prema pojedinim autorima se razlikuju. Tako Vresk (2002.) trgovački centar definira kao poslovni centar planski građen na većem prostoru, namijenjen trgovini na malo i drugim uslužnim djelatnostima, $s$ velikim parkiralištem za osobne automobile. Pri tome, prema obliku organizacije razlikuje dva tipa centara: integrirane centre sa zajedničkom upravom i neintegrirane centre u kojim pojedina poduzeća sama upravljaju prodajnim prostorima. Još se veća "pomutnja" javlja kada se uvedu i ostali pojmovi vezani uz maloprodajne oblike kao što su supermarketi, hipermarketi i specijalizirane prodavaonice. Razlike se javljaju kako u samoj terminologiji tako i u graničnim vrijednostima pojedinih površina. Tako Vresk (2002.) kao graničnu vrijednost između hipermarketa i supermarketa uzima površinu prodajnog prostora od $5000 \mathrm{~m}^{2}$. Istovremeno, drugi autori, poput Anića (1998.) kao graničnu vrijednost uzimaju površinu od $2500 \mathrm{~m}^{2}$, a istu graničnu vrijednost koristi i Hrvatska gospodarska komora. Konfuzija se javlja i u korištenju pojedinih pojmova. Tako pojedini autori, a također i pojedine statistike poput statistike Hrvatske gospodarske komore za sve maloprodajne objekte površine veće od $2500 \mathrm{~m}^{2}$ koriste naziv trgovački centar. Mi smo skloniji prikloniti se definiciji prema kojoj pojam trgovačkog centra isključuje maloprodajne prostore koji se sastoje od samo jednog prodajnog objekta ili su specijalizirani za prodaju samo malog broja proizvoda (Guy 1994). ${ }^{4}$

Tema ovog rada su trgovački centri grada Zagreba. Pri tome neće biti riječi o trgovačkim centrima u središtu grada, koji su do sada već bili tema pojedinih geografskih radova (npr. Lukić 2002) te se svojim izgledom i funkcijama značajno razlikuju od trgovačkih centara u prigradskim područjima, na rubovima grada te onih lociranih na križištima važnijih gradskih prometnica.

Trgovački centri u svijetu imaju stogodišnju tradiciju. Prvi trgovački centar izgrađen je u Baltimoreu 1907. godine, a 1923. godine izgrađen je Country Club Plaza u Kansas Cityu, prvi trgovački centar potpuno zatvorenog tipa na rubu grada (Pacione 2001; Guy 1994). Nakon toga je u Sjevernoj Americi uslijedio nagli porast broja trgovačkih centara na rubovima grada te jača proces suburbanizacije trgovine. Razlog tome su jaka automobilizacija te potrebe za sve većim slobodnim površinama. Istovremeno trgovina u središnjim dijelovima grada stagnira. ${ }^{5}$ Posljednjih nekoliko godina u Sjevernoj Americi je prisutan trend usporavanja rasta broja novootvorenih trgovačkih centara zbog nedostatka slobodnih površina, povećanja troškova zemljišta, strožih kontrola te otpora lokalnih zajednica (Goss 1993).

Razvoj trgovačkih centara u Europi je tekao nešto sporije te se prvi centri otvaraju tek '60-ih godina 20. stoljeća. Također vlasti su dugo vremena pokušavale ograničiti širenje trgovačkih centara u prigradske zone te područja tzv. Zelenog pojasa (green belt) oko 
gradova. Istovremeno se pokušavaju zadržati trgovačke funkcije centra grada (Davies, Baxter 1997).

Posljednjih godina najjači razvoj trgovačkih centara bilježe gradovi nekadašnje Demokratske Republike Njemačke gdje je veliko ulaganje kapitala te otvaranje prema zapadnonjemačkom tržištu rezultiralo otvaranjem velikog broja trgovačkih centara na rubnim dijelovima grada te u suburbanim zonama velikih gradova (Jürgens 1997).

Proces prijelaza s centralno - planske na tržišnu ekonomiju donio je uz opće društvene promjene i promjene u gospodarskim strukturama i u ostalim, nekad socijalističkim zemljama.

Trgovina na malo samo je jedna od gospodarskih aktivnosti koja se u najkraćem mogućem vremenu reorganizirala i prilagodila novim uvjetima (Standl 1998.). Najdinamičniji proces transformacije uočava se u prostornim strukturama u gradskim središtima, odnosno u lokaciji maloprodaje. Promjene se očituju u promjeni veličine i opremljenosti prodajnih prostora, strukturi robnog asortimana, vlasničkim odnosima proizašlim iz procesa privatizacije te otvaranjem velikog broja novih prodavaonica. Zemlje u tranziciji općenito karakteriziraju procesi privatizacije i formiranja novih trgovačkih tvrtki domaćih vlasnika uz istodobno propadanje do tada vodećih lanaca robnih kuća (lanac robnih kuća NAMA) te otvaranje tržišta stranim i međunarodnim trgovačkim lancima (Lukić 2002.). Ti su procesi prisutni i u Hrvatskoj iako je dolazak maloprodajnih lanaca u Hrvatsku započeo relativno kasno u odnosu na ostale zemlje u tranziciji. Razlozi tome bili su mala kupovna moć, nesređeni vlasničko - pravni odnosi i sl. ${ }^{6}$

Sredinom 90-ih godina otvaraju se trgovački centri u središnjem dijelu Zagreba. Prvi takav centar je Importanne centar, otvoren 1994. godine. Ubrzo nakon toga otvara se i Rotonda centar. Godine 1999. na tragu suburbanizacije trgovine otvara se u Donjem Stupniku i prvi trgovački centar na rubu grada, trgovački centar Mercatone. Danas se u središtu grada nalazi 5 trgovačkih centara različitih funkcija, a u rubnim dijelovima grada te na križanjima važnijih gradskih prometnica danas postoje još tri trgovačka centra. ${ }^{7}$

\section{CILJ I METODOLOGIJA RADA}

Cilj je rada prikazati razvoj trgovačkih centara na rubovima grada te na križanju glavnih gradskih prometnica. U radu je prikazan njihov položaj, struktura i funkcije. Cilj rada je bio istražiti trenutno stanje funkcija trgovačkih centara na rubovima grada te istražiti da li postoje razlike u razvijenosti funkcija između pojedinih centara. Hipoteza od koje se polazi u istraživanju je da su u trgovačkim centrima na rubu grada još uvijek primarno razvijene trgovačke funkcije dok su socijalne funkcije u drugom planu.

Podaci o površinama pojedinih trgovačkih centara prikupljeni su korištenjem sekundarnih izvora podataka i to korištenjem podataka Hrvatske gospodarske komore-Komore Zagreb te Državnog zavoda za statistiku. Podaci o strukturi pojedinih trgovačkih centara prikupljeni su metodom promatranja te kartiranjem djelatnosti u pojedinim trgovačkim centrima. 
Kako bi se dobili podaci o funkcijama trgovačkih centara provedeno je anketno ispitivanje, a korištena je i metoda intervjua. Anketno ispitivanje provedeno je u trgovačkim centrima King Cross, Mercator i Mercatone u razdoblju od 02. do 20. prosinca 2003. godine (tri dana u tjednu tijekom tri tjedna) pri čemu je anketirano 1159 posjetitelja. Kako bi se osigurala reprezentativnost ispitanici su birani metodom sistematskog uzorka ispitivanjem na ulazima / izlazima iz trgovačkih centara prilikom njihovog izlaza iz centra. U anketiranju je sudjelovalo 20 anketara većinom studenata III. i IV godine te apsolventi Geografskog odsjeka PMF-a. Većina anketara već je posjedovala određeno iskustvo u anketiranju u trgovačkim centrima.

U radu su osim podataka o trgovačkim centrima dani i podaci o pojedinim hipermarketima te kako bi se pokazala zonalnost u smještaju maloprodajnih oblika i lokacija supermarketa.

\section{PROSTORNI RAZMJEŠTAJ TRGOVAČKIH CENTARA I OSTALIH MALOPRODAJNIH TRGOVINA}

Općenito u Zagrebu razlikujemo tri osnovna tipa lokacije trgovačkih centara: u središtu grada, na križanjima važnijih gradskih prometnica te u blizini cestovnih čvorišta na rubovima grada. Kod supermarketa i hipermarketa prisutna je snažnija decentralizacija te se oni smještaju uz glavne izlazno - ulazne prometnice u grad te uz veća cestovna čvorišta na rubovima grada dok u središtu grada nisu prisutni. Takav trend prisutan je i u gradovima Europe i Sjeverne Amerike. Najčešći razlozi decentralizacije su okrupnjavanje prodajnih prostora, niže cijene zemljišta, veća dostupnost, mogućnost izgradnje većeg parkirnog prostora itd. (Hallsworth 1994; Gerhard 2001).

U ovom radu razmatraju se prvenstveno trgovački centri, a zatim i supermarketi i hipermarketi uz prometnice i cestovna čvorišta na rubu grada te uz industrijske zone (prvenstveno maloprodajni kompleks Žitnjak) ${ }^{8}$. Unutar tih skupina moguće je s obzirom na koncentraciju centara izdvojiti tri skupine lokacija.

Prvu skupinu čine supermarketi i hipermarketi uz Ljubljansku aveniju ili u njenoj neposrednoj blizini. Drugu skupinu čine supermarketi, hipermarketi i trgovački centri na istočnom dijelu grada duž Slavonske avenije, Ulice grada Vukovara, Ulice kneza Branimira i Ulice grada Gospića. Treću skupinu čine trgovački centri i hipermarketi u blizini autocestovnih čvorišta.

Ljubljanska avenija je cestovna prometnica ulazno - izlaznog karaktera (Kovačević 2002). Laka dostupnost centru grada s jedne te okolici s druge strane rezultirala je gradnjom brojnih prodajnih prostora. Izgradnja je koncentrirana duž Ljubljanske avenije zapadno od naselja Vrbani gdje je na duljini od svega četiri kilometra podignuto čak šest prodajnih prostora.

Slavonska avenija predstavlja produžetak Ljubljanske avenije te ulazno - izlaznu prometnicu prema istoku. Laka dostupnost Slavonske avenije s obilaznice te dobra povezanost s centrom grada (preko Ulice grada Vukovara) glavni su razlozi lokacije prodajnih prostora duž te prometnice. No kao važan faktor ističe se blizina industrijske zone Žitnjak, 


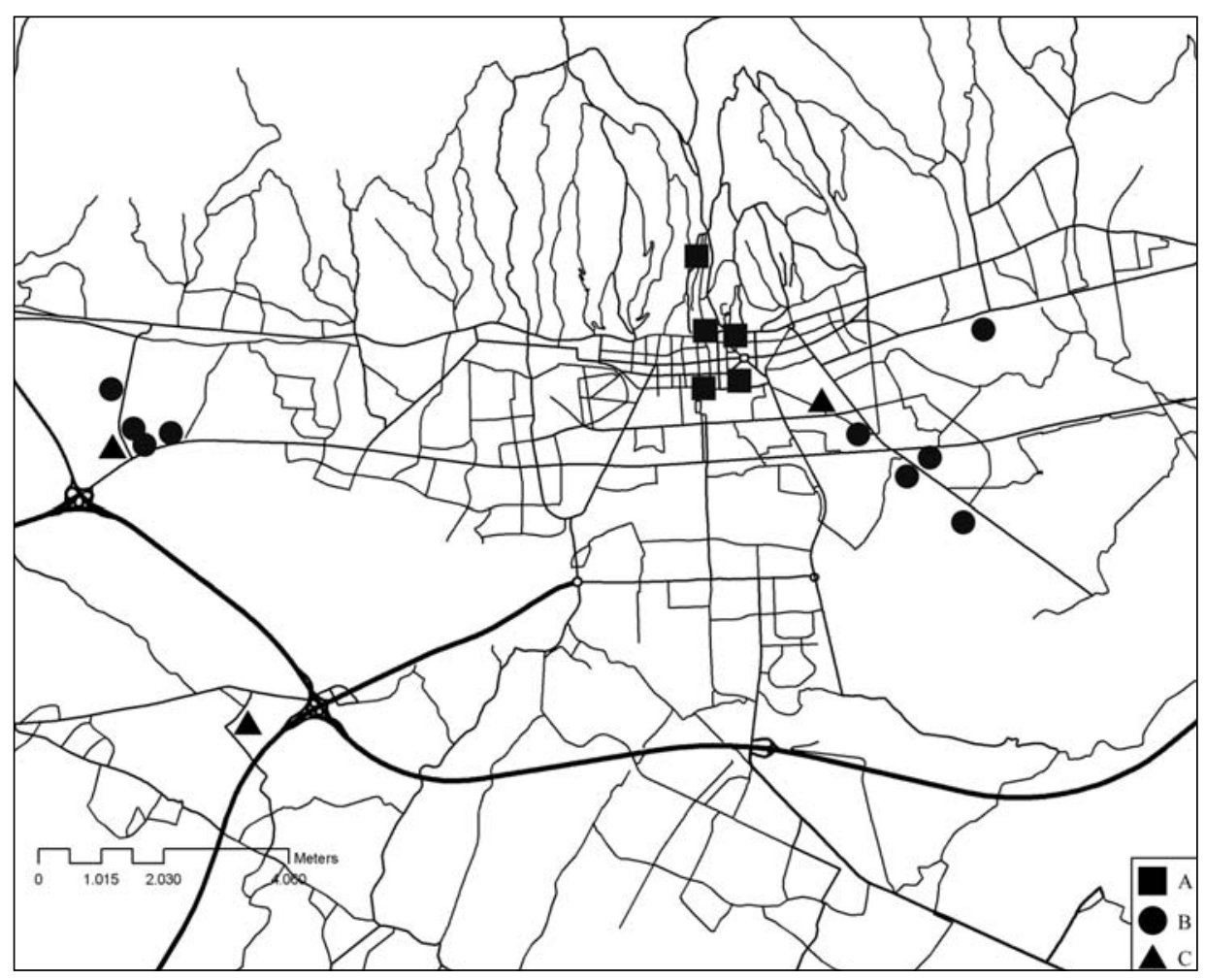

S1. 1. Prostorni razmještaj trgovačkih centara i hipermarketa u Zagrebu (A-trgovački centri u središtu grada; B-hipermarketi; C-trgovački centri u ostalim djelovima grada)

Fig. 1 Spatial distribution of shopping centres and hypermarkets in Zagreb (A-shopping centres in the city centre; B-hypermarkets; $C$-shopping centres in other parts of the city)

kao jedne od dviju glavnih industrijskih zona grada9 . Ulica grada Gospića i Ulica grada Vukovara pružaju se paralelno sa Slavonskom avenijom, u smjeru istok - zapad, te na svojevrstan način predstavljaju odvojke Slavonske avenije. Ulica kneza Branimira predstavlja glavnu ulazno - izlaznu prometnicu prema Sesvetama te se lokacija prodajnih prostora duž te prometnice može objasniti na isti način kao i lokacije duž Ljubljanske i Slavonske avenije. U ovoj zoni smješteno je čak 13 maloprodajnih prostora.

Treću skupinu čine maloprodajni prostori u blizini autocestovnih čvorišta na Zagrebačkoj obilaznici. Razlog tome je činjenica da čvorovi povećavaju dostupnost te su privlačni za smještaj tercijarnih aktivnosti (Sić 1997). Na Zagrebačkoj obilaznici postoji nekoliko čvorišta od kojih se posebno ističu čvorišta Jankomir i Lučko, kao dva najveća čvorišta. ${ }^{10}$ U posljednje dvije godine najznačajnije se razvio čvor Jankomir u kojem je na malom prostoru izgrađena trgovačka zona od čak 5 hipermarketa te King Cross, najveći trgovački centar u Hrvatskoj.

Otvaranje velikog broja hipermarketa i trgovačkih centara u relativno kratkom vremenu povlači za sobom pitanje gravitacijskog utjecaja pojedinih prodajnih prostora. Anketa 
provedena u tri prigradska trgovačka centra pokazala je da gotovo $92 \%$ posjetitelja živi na području grada Zagreba ili Zagrebačke županije. No razlike između pojedinih centara su značajne. Trgovački centar Mercator možemo smatrati primjerom trgovačkog centra gradskog značaja budući nešto više od $93 \%$ anketiranih posjetitelja živi na području grada Zagreba, a još $4.39 \%$ na području Zagrebačke županije. Trgovački centri Mercatone i King Cross primjeri su trgovačkih centara koji opslužuju područje metropolitanske regije Zagreba.

Tab. 1. Posjetitelji trgovačkih centara prema mjestu stanovanja

Tab. 1 Visitors of shopping centres according to residence

\begin{tabular}{|l|c|c|c|c|c|c|c|}
\hline $\begin{array}{c}\text { Trgovački } \\
\text { centar }\end{array}$ & Zagreb & $\begin{array}{c}\text { Zagrebačka } \\
\text { županija }\end{array}$ & $\begin{array}{c}\text { Susjedne } \\
\text { županije }\end{array}$ & $\begin{array}{c}\text { Drugdje u } \\
\text { Hrvatskoj }\end{array}$ & $\begin{array}{c}\text { Izvan } \\
\text { Hrvatske }\end{array}$ & Nepoznato & Ukupno \\
\hline King Cross & 68,29 & 20,14 & 5,32 & 4,63 & 0,93 & 0,69 & 100,00 \\
\hline Mercator & 93,41 & 4,39 & - & 1,95 & 0,24 & 0,01 & 100,00 \\
\hline Mercatone & 78,55 & 10,73 & 2,21 & 7,57 & 0,63 & 0,31 & 100,00 \\
\hline Ukupno & 79,98 & 11,99 & 2,59 & 4,49 & 0,61 & 0,34 & 100,00 \\
\hline
\end{tabular}

Izvor: Anketno ispitivanje

Source: Survey

Zanimljiv je i odnos posjetitelja koji žive na području grada Zagreba. U sva tri trgovačka centra više od 50\% anketiranih posjetitelja živi u četvrti u kojoj se nalazi dotični trgovački centar ili u nekoj od susjednih četvrti grada. Taj postotak je opet najizraženiji u trgovačkom centru Mercator gdje iznosi čak 58\% od ukupnog broja anketiranih stanovnika s područja grada Zagreba dolazi iz iste četvrti.

Većina posjetitelja, njih $86 \%$ u trgovačke centre dolazi osobnim automobilom, a podjednak broj ih dolazi sredstvima javnog gradskog prijevoza $(6.7 \%)$ i pješice $(6.6 \%)$. Gotovo je zanemariv broj posjetitelja koji u trgovačke centre dolaze posebnim autobusnim linijama (svega $0.2 \%$ ). ${ }^{11}$ Podaci se znatno razlikuju među pojedinim trgovačkim centrima. Očekivano najmanji udio posjetitelja koji u trgovački centar dolaze osobnim automobilom ima Mercator (75\%). Istovremeno Mercator ima i najveći udio broja posjetitelja koji u centar dolaze pješice (14\%) te javnim gradskim prijevozom (13\%). Takav omjer moguće je objasniti lokacijom trgovačkog centra Mercator, dobrim tramvajskim vezama s središnjim dijelovima grada te blizinom gradskih četvrti s izraženom stambenom funkcijom. Pomalo neočekivane rezultate pokazale su ankete provedene u trgovačkim centrima King Cross $\mathrm{i}$ Mercatone. Usprkos većem broju autobusnih linija gradskog i prigradskog prometa gotovo $97 \%$ ispitanika u King Cross dolazi osobnim automobilom, a svega $2 \%$ dolazi javnim gradskim prijevozom. Istovremeno u Mercatone $90 \%$ stanovnika dolazi osobnim automobilom, a 5\% javnim gradskim prijevozom. Iznenađujući je i udio od $4.5 \%$ posjetitelja koji u Mercatone dolaze pješice iz susjednih naselja Hrvatski Leskovac i Lučko. 


\section{STRUKTURA POSLOVNIH PROSTORA I FUNKCIJE TRGOVAČKIH CENTARA}

Kao što je već rečeno u uvodu u rubnim područjima grada Zagreba te na križanju važnijih gradskih prometnica postoje tri trgovačka centra: Mercatone, Mercator i King Cross te veliki broj hipermarketa. U tablici 2. su pregledno dane površine hipermarketa i trgovačkih centara u gradu Zagrebu pri čemu su uključeni i trgovački centri u središnjem dijelu grada.

Iz definicije trgovačkih centara se vidi da je jedna od glavnih karakteristika trgovačkih centara postojanje osiguranog parkirališnog prostora. Sva tri prigradska trgovačka centra u Zagrebu imaju osigurane parkirališne prostore, no samo Mercator ima osigurano natkriveno parkiralište. Za razliku od njih trgovački centri u središnjim dijelovima grada imaju osigurana natkrivena više - etažna parkirališta. Glavni razlog tome je nedostatak slobodnog prostora.

Sve trgovačke centre karakterizira slaba prilagođenost osobama s invaliditetom, koja se svodi na postojanje nekoliko parkirališnih mjesta te eventualno posebnih košarica za kupovinu.

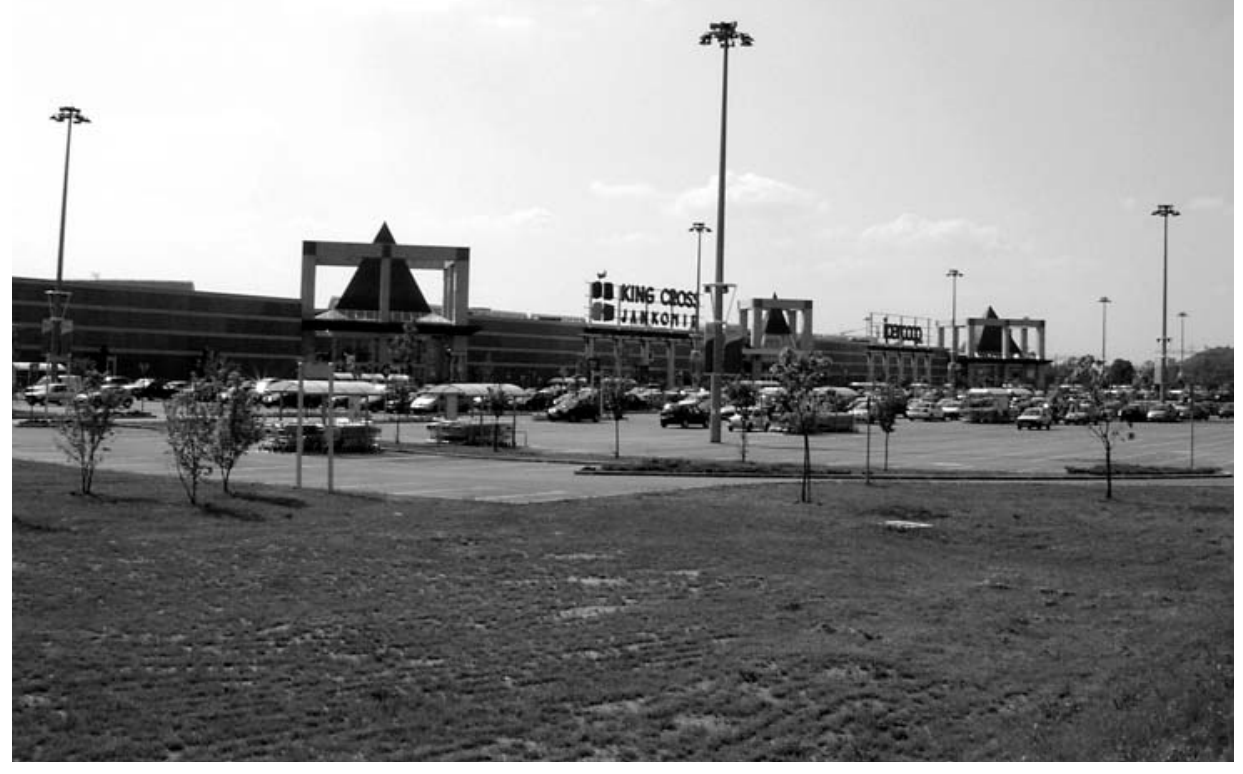

S1. 2. King Cross, primjer trgovačkog centra na rubu grada

Fig. 2 King Cross, an example of a shopping centre at the outskirts of the city 


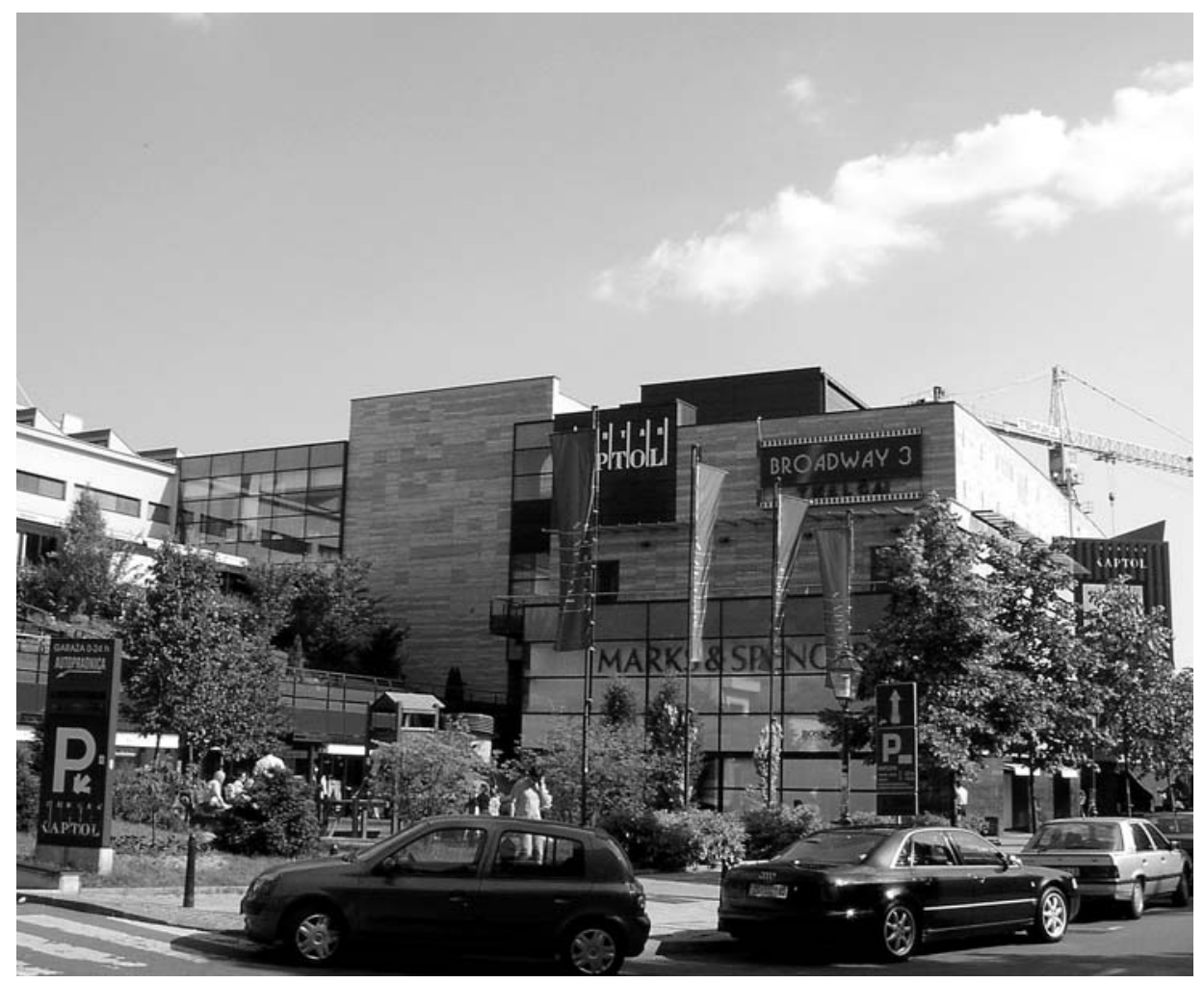

S1. 3. Kaptol Centar, primjer trgovačko - poslovnog kompleksa u središtu grada

Fig. 3 Kaptol Centar, an example of shopping and business centre in the downtown

Sva tri trgovačka centra imaju hipermarket površine veće od $5000 \mathrm{~m}^{2}$ u kojemu se roba prodaje po principu samoposluživanja. Broj lokala po pojedinom trgovačkom centru se značajno razlikuje. Tako se u trgovačkom centru King Cross nalazi uz hipermarket još 93 lokala različitih trgovačkih i uslužnih funkcija. U ostalim trgovačkim centrima njihov broj je znatno manji te iznosi 25 lokala u trgovačkom centru Mercatone te $30 \mathrm{u}$ trgovačkom centru Mercator.

Kao što je naglašeno u uvodu postoje dvije osnovne funkcije trgovačkih centara: trgovačke i socijalne funkcije. Centri u Europi i Sjevernoj Americi sve više nude sve što je kupcu potrebno na jednom mjestu. Takvom poslovnom politikom centar privlači kupca, a kupac štedi vrijeme. ${ }^{12}$ No da bi se omogućilo provođenje takove poslovne politike potrebno je da trgovački centar posjeduje razvijene sve funkcije i sve vrste usluga. Promatrana tri trgovačka centra još uvijek ne omogućuju takav oblik kupovanja.

Iz podataka dobivenih kartiranjem na terenu vidljivo je da je čak $64.9 \%$ od ukupnog broja lokala namijenjeno trgovini na malo. Podaci između pojedinih centara se znatno razlikuju te se kreću od 50\% u trgovačkom centru Mercatone do 70\% u trgovačkom centru King Cross. No pri analizi pojedinih trgovačkih centara uzimanje u obzir samo strukture 
Tab. 2. Trgovački centri i hipermarketi u Zagrebu

Tab. 2 Shopping centres and hypermarkets in Zagreb

\begin{tabular}{|c|c|c|c|}
\hline \multicolumn{4}{|c|}{ Trgovački centri } \\
\hline Naziv & Adresa & $\begin{array}{l}\text { Površina prodajnog } \\
\text { prostora }\left(\mathbf{m}^{2}\right)\end{array}$ & Datum otvaranja \\
\hline Importanne Centar & Trg A. Starčevića b & 35000 & 1994. \\
\hline Rotonda Centar & Jurišićev & 2200 & \\
\hline Kaptol Centar & Nova Ves & 43000 & 14.12.2000. \\
\hline Importanne Galleria & Iblerov trg 10 & 47000 & 1999. \\
\hline Branimir Centar & Branimirova & - & 2003. \\
\hline King Cross & Velimira Škorpika 34 & 43000 & 22.09 .2002 . \\
\hline Mercatone & Gospodarska ulica bb & 36000 & 01.12.1999. \\
\hline Mercator Zagreb & Ul. grada Vukovara 269 & 15000 & 14.09 .2001$. \\
\hline \multicolumn{4}{|c|}{ Hipermarketi } \\
\hline Getro Sesvete & Ljudevita Posavskog 5 & 8500 & 07.11 .1994$. \\
\hline Bauhaus Žitnjak & Žitnjak bb & 8000 & 2000. \\
\hline Bauhaus Jankomir & Ljubljanska avenija & 11000 & 12.12 .2003 \\
\hline Gramat Baumarket & Radnička cesta 184 & 6000 & Lipanj 2000. \\
\hline Kaufland & Kneza Branimira 119 & 5186 & 04.09 .2003 \\
\hline Merkur & Slavonska avenija 106 & 6000 & 2002 \\
\hline Pevec & Ulica grada Gospića & 6000 & 1998. \\
\hline Pevec Jankomir & Jankomir & 8000 & Prosinac 2003. \\
\hline RK Doma & Žitnjak bb & 8300 & 07.09 .2001 \\
\hline Baumax - X & Velimira Škorpika bb & 11300 & 04.11 .2003 \\
\hline
\end{tabular}

Izvor: Podaci Uprava trgovačkih centara i HGK

Source: Management of shopping centres, Croatian Chamber of Commerce

poslovnih prostora trgovačkih centara prema broju objekata pojedine namijene može navesti na krive zaključke. Naime ukoliko bi se umjesto broja lokala promatrala struktura trgovačkih centara prema površini poslovnih prostora mogli bi se dobiti znatno drugačiji podaci. U slučaju promatranih centara na rubu grada te u blizini glavnih prometnica $i$ dalje u površini prevladavaju lokali namijenjeni trgovini na malo no u centrima u središtu grada razlike su znatne. ${ }^{13}$

Općenito možemo reći da u zemljama Zapadne Europe i Sjeverne Amerike trgovački centri nisu samo oblik maloprodaje, već sve više i postmoderno mjesto potrošnje u kojemu se istovremeno isprepliću trgovina i razonoda (Holbrook, Jackson 1996). Oni su "katedrale potrošnje", mjesta na kojima je kupovina izraz prestiža, moći i simbolizma znatno više nego jednostavne ekonomske potrebe (Gregson 1995; Gerhard 2001). Pojedini centri razvijaju i turističku funkciju postajući turističke destinacije (Goss 1993). 
Tab. 3. Broj i struktura poslovnih prostora u trgovačkim centrima King Cross, Mercatone i Mercator Tab. 3 Number and structure of outlets in shopping centres King Cross, Mercatone and Mercator

\begin{tabular}{|l|c|c|c|c|c|c|}
\hline \multirow{2}{*}{ Vrsta poslovnog prostora } & \multicolumn{2}{|c|}{ King Cross } & \multicolumn{2}{c|}{ Mercator } & \multicolumn{2}{c|}{ Mercatone } \\
\cline { 2 - 7 } & Broj & $\%$ & Broj & \% & Broj & $\%$ \\
\hline Trgovina na malo & 66 & 70,20 & 19 & 61,29 & 13 & 50,00 \\
\hline Hipermarket & 1 & 1,06 & 1 & 3,23 & 1 & 3,85 \\
\hline Odjeća i obuća, dječje igrač & 45 & 47,87 & 12 & 38,71 & 7 & 26,92 \\
\hline Oprema za kuću u tehnička rob & 6 & 6,38 & 2 & 6,45 & 2 & 7,69 \\
\hline $\begin{array}{l}\text { Cvjećarnice, poklon galerije, } \\
\text { kiosci, satovi i nakit, kozmetik }\end{array}$ & 14 & 14,89 & 4 & 12,90 & 3 & 11,54 \\
\hline Usluge & 11 & 11,69 & 5 & 16,13 & 5 & 19,23 \\
\hline Kozmetički i frizerski saloni & 1 & 1,06 & 1 & 3,23 & - & - \\
\hline Ljekarna & 1 & 1,06 & - & - & 1 & 3,85 \\
\hline Optike & 2 & 2,13 & 1 & 3,23 & 1 & 3,85 \\
\hline Hrvatska lutrija i kladionice & 2 & 2,13 & 1 & 3,23 & 1 & 3,85 \\
\hline Foto studio & 2 & 2,13 & 1 & 3,23 & 1 & 3,85 \\
\hline Igraonice & 1 & 1,06 & 1 & 3,23 & 1 & 3,85 \\
\hline $\begin{array}{l}\text { Sitni popravci (postolar, } \\
\text { bravar...) }\end{array}$ & 1 & 1,06 & - & - & - & - \\
\hline Turističke agencije & 1 & 1,06 & - & - & - & - \\
\hline Financijske usluge & 3 & 3,19 & 3 & 9,68 & 3 & 11,54 \\
\hline Banke / poslovnica FINE & 2 & 2,13 & 2 & 6,45 & 2 & 7,69 \\
\hline Mjenjačnice & 1 & 1,06 & 1 & 3,23 & 1 & 3,85 \\
\hline Ugostiteljske usluge & 14 & 14,89 & 4 & 12,90 & 5 & 19,23 \\
\hline Kafić & 8 & 8,51 & 3 & 9,68 & 2 & 7,69 \\
\hline $\begin{array}{l}\text { Restorani, snack bar, } \\
\text { slastičarnice }\end{array}$ & 64,38 & 1 & 3,23 & 3 & 11,54 \\
\hline Ukupno & 100,00 & 31 & 100,00 & 26 & 100,00 \\
\hline
\end{tabular}

Izvor: Terensko kartiranje

Source: Mapping

Kako bi se pridonijelo privlačnosti prostora te ugodnosti kupovanja u trgovačkim centrima se uređuju šetnice, fontane, prostori za odmor i sl. Trgovački centri postaju mjesta okupljanja koja su svima dostupna (Goss 1993). ${ }^{14}$

Kako bi se pokazala razvijenost funkcija promatranih trgovačkih centara provedeno je anketno ispitivanje u kojemu se nekoliko pitanja odnosilo na razloge dolaska u pojedini trgovački centar. Ispitivano je i s kim su posjetitelji došli u trgovački centar te da li su prilikom posjeta tog dana bili u kafiću ili restoranu. 


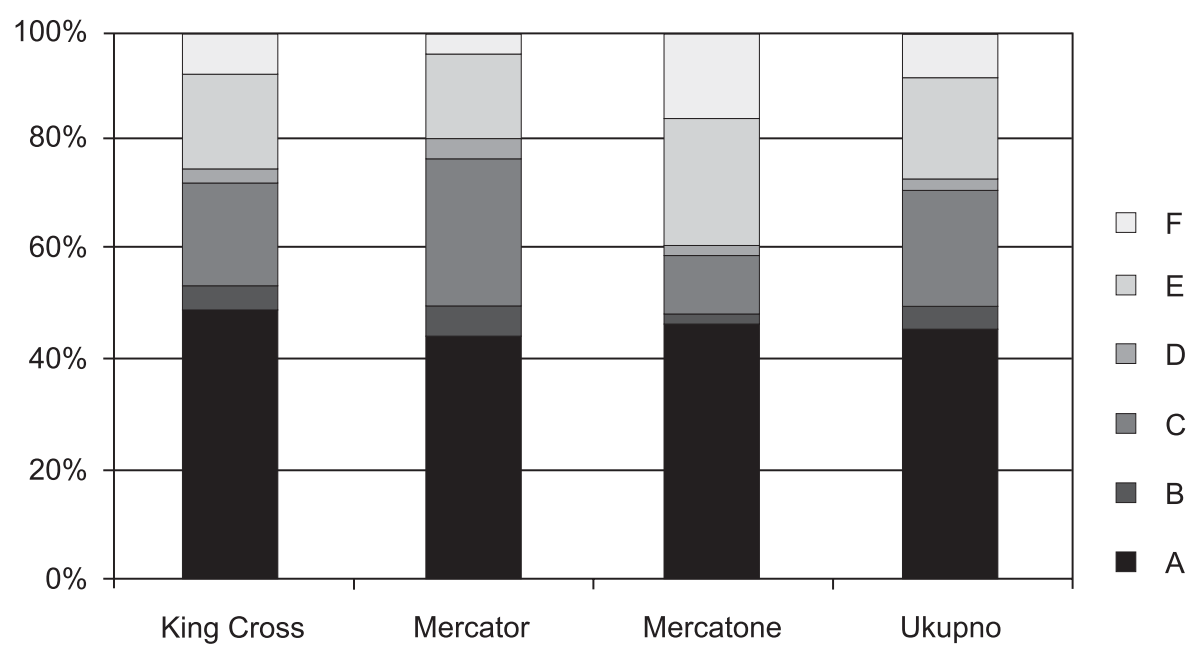

\begin{tabular}{ccccc}
\hline & King Cross & Mercator & Mercatone & Ukupno \\
\hline A & 49,27 & 44,49 & 46,69 & 46,02 \\
\hline B & 4,39 & 5,38 & 1,58 & 3,89 \\
\hline C & 18,78 & 27,38 & 11,04 & 21,11 \\
\hline D & 2,19 & 2,44 & 1,26 & 1,99 \\
\hline E & 17,32 & 16,14 & 23,34 & 18,25 \\
\hline F & 8,05 & 4,16 & 16,09 & 8,73 \\
\hline
\end{tabular}

S1. 4. Glavni razlozi dolaska u pojedini trgovački centar - dnevni prosjek

A-kupovina; B-ponuda pratećih i ugostiteljskih usluga; C-ugodan ambijent; D-druženje s prijateljima; E-laka dostupnost; F-ostalo

Fig. 4 Main reasons for visiting specific shopping centre-daily average

$A$-retail; B-additional and catering facilities; $C$-pleasant environment; D-socializing with friends; E-accessibility; F-other

Čak 46,02\% ispitanika kao glavni razlog svog dolaska navelo je kupovinu te dobru ponudu robe, a svega 1,99\% ispitanika kao glavni razlog svog dolaska navodi druženje s prijateljima. Dobru ponudu pratećih i ugostiteljskih funkcija kao glavni razlog dolaska navodi 3,89\% ispitanika, što pokazuje jačanje uslužnih funkcija u trgovačkim centrima te produljenje boravka posjetitelja u centru. To potvrđuje i podatak da je čak 30,7\% od ukupno anketiranih tijekom svog boravka u trgovačkom centru posjetilo kafić i restoran. Razlike između pojedinih centara nisu prevelike iako je bilo za očekivati da će zbog smještaja Mercatora u stambenoj četvrti veći broj ispitanika kao glavni razlog dolaska u trgovački centar navesti druženje s prijateljima. Razlozi dolaska u trgovački centar se ne mijenjaju značajno u odnosu na vrijeme ispitivanja što dokazuje gotovo isključivu monofunkcionalnost trgovačkih centara. ${ }^{15}$ 
Tab. 4. Glavni razlog dolaska u pojedini trgovački centar prema dobima dana

$\mathrm{A}=$ kupovina, $\mathrm{B}=$ ponuda pratećih $\mathrm{i}$ ugostiteljskih usluga, $\mathrm{C}=$ ugodan ambijent, $\mathrm{D}=$ druženje $\mathrm{s}$ prijateljima, $\mathrm{E}=$ laka dostupnost, $\mathrm{F}=$ ostalo

Tab. 4 Main reasons for visiting specific shopping centre according to time of the day

A-retail; B-additional and catering facilities; $C$-pleasant environment; $D$-socializing with friends;

E-accessibility; $F$-other

\begin{tabular}{|c|c|c|c|c|c|c|c|c|}
\hline \multirow{2}{*}{ Odgovor } & \multicolumn{2}{|c|}{ King Cross } & \multicolumn{2}{c|}{ Mercator } & \multicolumn{2}{c|}{ Mercatone } & \multicolumn{2}{c|}{ Ukupno } \\
\cline { 2 - 8 } & Broj & $\%$ & Broj & $\%$ & Broj & $\%$ & Broj & $\%$ \\
\hline
\end{tabular}

\section{1:00 - 12:00}

\begin{tabular}{|c|r|r|r|r|r|r|r|r|}
\hline $\mathrm{A}$ & 41 & 43,16 & 59 & 49,17 & 44 & 48,35 & 144 & 47,05 \\
\hline $\mathrm{B}$ & 6 & 6,31 & 8 & 6,67 & 2 & 2,19 & 16 & 5,23 \\
\hline $\mathrm{C}$ & 21 & 22,11 & 34 & 28,33 & 10 & 10,99 & 65 & 21,24 \\
\hline $\mathrm{D}$ & 2 & 2,11 & 1 & 0,83 & 2 & 2,19 & 5 & 1,63 \\
\hline $\mathrm{E}$ & 12 & 12,63 & 12 & 10,00 & 21 & 23,07 & 45 & 14,71 \\
\hline $\mathrm{F}$ & 13 & 13,68 & 6 & 5,00 & 12 & 13,19 & 31 & 12,13 \\
\hline Ukupno & 95 & 100,00 & 120 & 100,00 & 91 & 100,00 & 100,00 & 100,00 \\
\hline
\end{tabular}

\section{3:00 - 14:00}

\begin{tabular}{|c|r|r|r|r|r|r|r|r|}
\hline $\mathrm{A}$ & 47 & 49,47 & 57 & 47,11 & 46 & 51,11 & 150 & 41,66 \\
\hline $\mathrm{B}$ & 1 & 1,05 & 7 & 5,78 & - & - & 8 & 2,61 \\
\hline $\mathrm{C}$ & 23 & 24,21 & 27 & 22,31 & 11 & 12,22 & 61 & 19,93 \\
\hline $\mathrm{D}$ & 4 & 4,21 & 4 & 3,31 & 2 & 2,22 & 10 & 3,27 \\
\hline $\mathrm{E}$ & 17 & 17,89 & 25 & 2,07 & 18 & 20,00 & 60 & 19,61 \\
\hline $\mathrm{F}$ & 3 & 3,16 & 1 & 0,83 & 13 & 14,44 & 17 & 5,55 \\
\hline Ukupno & 95 & 100,00 & 121 & 100,00 & 90 & 100,00 & 306 & 100,00 \\
\hline
\end{tabular}

\section{6:00 - 17:00}

\begin{tabular}{|c|r|r|r|r|r|r|r|r|}
\hline $\mathrm{A}$ & 57 & 50,44 & 30 & 35,29 & 35 & 40,69 & 122 & 42,96 \\
\hline $\mathrm{B}$ & 4 & 3,54 & 4 & 4,71 & 2 & 2,33 & 10 & 3,52 \\
\hline $\mathrm{C}$ & 23 & 20,35 & 28 & 32,94 & 8 & 9,30 & 59 & 20,77 \\
\hline $\mathrm{D}$ & 2 & 17,69 & 3 & 3,53 & - & - & 5 & 1,76 \\
\hline $\mathrm{E}$ & 18 & 15,93 & 16 & 18,82 & 23 & 26,74 & 57 & 20,07 \\
\hline $\mathrm{F}$ & 9 & 7,96 & 4 & 4,71 & 18 & 20,93 & 31 & 10,91 \\
\hline Ukupno & 113 & 100,00 & 85 & 100,00 & 86 & 100,00 & 284 & 100,00 \\
\hline
\end{tabular}

\section{8:00 - 19:00}

\begin{tabular}{|c|r|r|r|r|r|r|r|r|}
\hline $\mathrm{A}$ & 57 & 43,51 & 36 & 42,86 & 23 & 46,00 & 116 & 43,77 \\
\hline $\mathrm{B}$ & 7 & 5,34 & 3 & 3,57 & 1 & 2,00 & 11 & 4,15 \\
\hline $\mathrm{C}$ & 30 & 22,90 & 23 & 27,38 & 6 & 12,00 & 59 & 22,26 \\
\hline $\mathrm{D}$ & 1 & 0,76 & 3 & 3,57 & - & - & 4 & 1,51 \\
\hline $\mathrm{E}$ & 28 & 21,37 & 13 & 15,47 & 12 & 24,00 & 53 & 20,00 \\
\hline $\mathrm{F}$ & 8 & 6,11 & 6 & 7,14 & 8 & 16,00 & 22 & 8,30 \\
\hline Ukupno & 131 & 100,00 & 84 & 100,00 & 50 & 100,00 & 265 & 100,00 \\
\hline
\end{tabular}

Izvor: Anketno ispitivanje

Source: Survey 


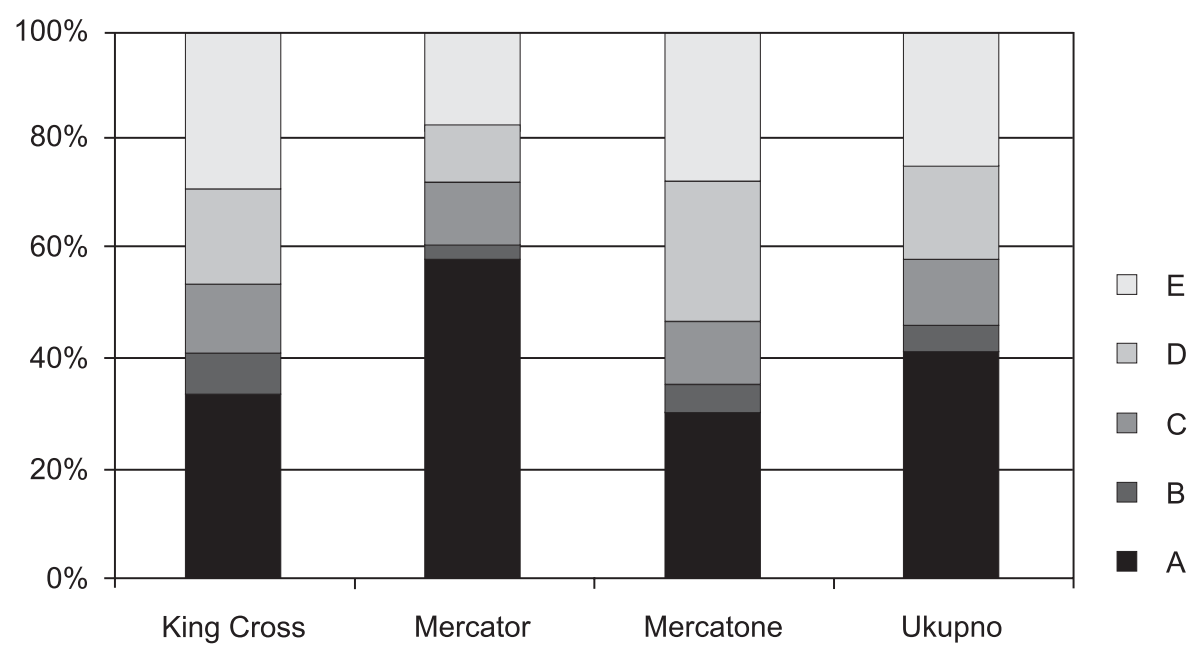

\begin{tabular}{ccccc}
\hline & King Cross & Mercator & Mercatone & Ukupno \\
\hline A & 33,49 & 57,8 & 30,28 & 41,58 \\
\hline B & 6,71 & 2,68 & 5,67 & 5 \\
\hline C & 12,73 & 12,19 & 11,67 & 12,25 \\
\hline D & 17,82 & 9,51 & 25,55 & 16,99 \\
\hline E & 28,24 & 17,8 & 26,81 & 24,16 \\
\hline
\end{tabular}

S1. 5. S kim ste danas posjetili trgovački centar?

A- sam / sama, B- s dečkom / djevojkom, C- s prijateljima, D- s bračnim partnerom, E- s obitelji

Fig. 5 With whom did you visit the shopping centre?

A-alone, $B$ - with boyfried/girlfriend, $C$-with friends, D-with husband/wife, E-with family

Iz navedenih podataka te detaljnijih podataka danih u tablici (Tab. 4) vidljivo je da trgovački centri na rubnim dijelovima grada i dalje imaju značajnije jače razvijene trgovačke funkcije, dok su socijalne funkcije još uvijek relativno slabo razvijene. To potvrđuje i činjenica da je čak 41,58\% ispitanika sam / sama posjetila trgovački centar (Tab. 5). Iz tablice je također očito da postoje i razlike između pojedinih doba dana te da udio posjetitelja koji sami dolaze u trgovački centar opada od jutra prema večeri. Jednako tako udio posjetitelja koji u centar dolaze s obitelji ili bračnim partnerom se povećava.

Svi do sada navedeni podaci jasno ukazuju da iako trgovački centri pokušavaju svoje prostore učiniti privlačnijima kupcima te ugodnijima za dulji boravak ipak je prvotni naglasak na trgovačkim funkcijama. Takvi rezultati potvrđeni su i u razgovorima s voditeljima pojedinih trgovačkih centara koji su svi u prvom redu kao glavne smjernice svog poslovanja isticali povećanje raznolikosti trgovačke ponude te daljnji razvoj trgovačkih funkcija. Razlike između pojedinih centara naravno postoje no one su očitije jedino u slučaju King Crossa koji svoju ponudu pokušava oplemeniti zabavnim sadržajima, nastupima zabavljača 
te brojnim nagradnim igrama te se profilirati u trgovački centar obiteljske kupovine, no za sada nije realno očekivati da će u skorije vrijeme trgovački centri na rubovima grada te križanjima važnijih prometnica ponudom socijalnih i kulturnih funkcija moći konkurirati centrima u središtu grada.

Tab. 5. S kim ste danas posjetili trgovački centar?

A- sam / sama, B- s dečkom / djevojkom, C- s prijateljima, D- s bračnim partnerom, E- s obitelji

Tab. 5 With whom did you visit the shopping centre?

$A$ - alone, $B$-with boyfried/girlfriend, $C$-with friends, D-with husband/wife, E-with family

\begin{tabular}{|c|c|c|c|c|c|c|c|c|}
\hline \multirow{2}{*}{ Odgovor } & \multicolumn{2}{|c|}{ King Cross } & \multicolumn{2}{c|}{ Mercator } & \multicolumn{2}{c|}{ Mercatone } & \multicolumn{2}{c|}{ Ukupno } \\
\cline { 2 - 8 } & Broj & $\%$ & Broj & $\%$ & Broj & $\%$ & Broj & $\%$ \\
\hline
\end{tabular}

\section{1:00 - 12:00}

\begin{tabular}{|c|r|r|r|r|r|r|r|r|}
\hline $\mathrm{A}$ & 47 & 51,65 & 77 & 64,17 & 33 & 36,67 & 157 & 52,16 \\
\hline $\mathrm{B}$ & 1 & 1,09 & 2 & 1,66 & 3 & 3,33 & 6 & 1,99 \\
\hline $\mathrm{C}$ & 11 & 12,08 & 15 & 12,5 & 13 & 14,44 & 39 & 12,96 \\
\hline $\mathrm{D}$ & 15 & 16,48 & 10 & 8,33 & 22 & 24,44 & 47 & 15,61 \\
\hline $\mathrm{E}$ & 17 & 18,68 & 16 & 13,33 & 19 & 21,11 & 52 & 17,27 \\
\hline Ukupno & 91 & 100,00 & 120 & 100,00 & 90 & 100,00 & 301 & 100,00 \\
\hline
\end{tabular}

\section{3:00 - 14:00}

\begin{tabular}{|c|r|r|r|r|r|r|r|r|}
\hline A & 32 & 32,99 & 69 & 57,02 & 30 & 33,33 & 131 & 42,53 \\
\hline $\mathrm{B}$ & 5 & 5,15 & 1 & 0,83 & 3 & 3,33 & 9 & 2,92 \\
\hline $\mathrm{C}$ & 15 & 15,46 & 16 & 13,22 & 7 & 7,78 & 38 & 12,34 \\
\hline $\mathrm{D}$ & 18 & 18,55 & 10 & 8,26 & 24 & 26,66 & 52 & 16,88 \\
\hline $\mathrm{E}$ & 27 & 27,83 & 25 & 20,66 & 26 & 28,88 & 78 & 25,32 \\
\hline Ukupno & 97 & 100,00 & 121 & 100,00 & 90 & 100,00 & 308 & 100,00 \\
\hline
\end{tabular}

\section{6:00 - 17:00}

\begin{tabular}{|c|r|r|r|r|r|r|r|r|}
\hline A & 43 & 38,05 & 47 & 55,29 & 20 & 23,26 & 110 & 38,73 \\
\hline $\mathrm{B}$ & 5 & 4,42 & 4 & 4,71 & 9 & 10,46 & 18 & 6,34 \\
\hline $\mathrm{C}$ & 12 & 10,62 & 10 & 11,76 & 14 & 16,28 & 36 & 12,68 \\
\hline $\mathrm{D}$ & 21 & 18,58 & 9 & 10,59 & 20 & 23,25 & 50 & 17,61 \\
\hline $\mathrm{E}$ & 32 & 28,32 & 15 & 17,65 & 23 & 26,74 & 70 & 24,65 \\
\hline Ukupno & 113 & 100,00 & 85 & 100,00 & 86 & 100,00 & 284 & 100,00 \\
\hline
\end{tabular}

\section{8:00 - 19:00}

\begin{tabular}{|c|r|r|r|r|r|r|r|r|}
\hline $\mathrm{A}$ & 27 & 20,61 & 44 & 52,38 & 12 & 24,00 & 83 & 31,32 \\
\hline $\mathrm{B}$ & 18 & 13,74 & 4 & 4,76 & 3 & 6,00 & 25 & 9,43 \\
\hline $\mathrm{C}$ & 17 & 12,98 & 9 & 10,71 & 3 & 6,00 & 29 & 10,94 \\
\hline $\mathrm{D}$ & 23 & 17,56 & 10 & 11,90 & 15 & 30,00 & 48 & 18,11 \\
\hline $\mathrm{E}$ & 46 & 35,11 & 17 & 20,24 & 17 & 34,00 & 80 & 30,19 \\
\hline Ukupno & 131 & 100,00 & 84 & 100,00 & 50 & 100,00 & 265 & 100,00 \\
\hline
\end{tabular}

Izvor: Anketno ispitivanje

Source: Survey 


\section{ZAKLJUČAK}

Prvi trgovački centri u svijetu otvaraju se 1920-ih godina. U Zagrebu se trgovački centri javljaju čak sedamdesetak godina kasnije. U prvoj fazi, sredinom 1990-ih javljaju se trgovački centri u središtu grada te relativno brzo postaju ne samo mjesta kupovine već i mjesta druženja i provođenja slobodnog vremena. Prvi trgovački centar na rubu grada je Mercatone otvoren tek 1999. godine. Nakon toga uslijedilo je otvaranje i preostala dva trgovačka centra.

Iako se sva tri trgovačka centra nalaze na rubovima grada ili u blizini glavnih prometnica njihov gravitacijski utjecaj se znatno razlikuje. Trgovački centar Mercator može se uzeti kao primjer trgovačkog centra gradskog značenja, u kojemu 93,41\% posjetitelja dolazi iz Zagreba a 58\% posjetitelja dolazi iz iste gradske četvrti, dok su Mercatone i King Cross primjeri centara regionalnog značenja.

Općenito postoje značajne razlike između funkcija trgovačkih centara u središtu Zagreba te trgovačkih centara u njegovim rubnim zonama. Dok trgovački centri u središtu Zagreba imaju uz trgovačke razvijene i socijalne, poslovne, a poneki čak i stambene funkcije, trgovački centri u rubnim područjima bilježe dominaciju trgovačkih funkcija. Na temelju podataka o razlozima dolaska u pojedini trgovački centar, dobivenih anketiranjem u sva tri trgovačka centra pokazano je da posjetitelji trgovačkih centara u rubnim dijelovima grada još uvijek ne percipiraju te centre kao mjesta druženja i provođenja slobodnog vremena već prvenstveno kao mjesta kupovine te da u Zagrebu još uvijek postoji razdvojenost mjesta zabave i mjesta kupovine, pri čemu zabava ostaje u središtu grada. U prosjeku preko $46 \%$ anketiranih kao glavni razlog dolaska navode kupovinu a svega 1,99\% druženje s prijateljima. Razlog tome treba tražiti i u politici poslovanja uprava trgovačkih centara koje, iako se izgledom centara pokušavaju približiti trgovačkim centrima u središtu grada te ih učiniti privlačnijim za posjetitelje, još uvijek naglasak stavljaju gotovo isključivo na razvoj trgovačkih funkcija.

\section{ZAHVALA}

Ovime zahvaljujemo svima koji su nam pomogli u izradi članka, a posebno: Aleksandru Lukiću, prof., dr.sc. Milanu Iliću, mr.sc. Vlasti Klarić, prof. dr. Miroslavu Siću i prof. dr.sc. Aleksandru Toskiću te apsolventima i studentima III i IV godine Geografskog odsjeka PMF-a.

\section{POZIVNE BILJEŠKE}

1. U anglosaksonskoj literaturi uobičajen je naziv "retail geography"

2. Za virtualnu kupovinu i kupovinu putem kataloga u anglosaksonskoj literaturi se često koristi naziv "window shopping"

3. Definicija International Council of Shopping Centers Research. Anić (1998.) vrlo slično definira trgovački centar smatrajući ga skupom maloprodajnih objekata različitih maloprodajnih i uslužnih poduzeća koji se razvijaju i planiraju kao jedno poduzeće i kojima se sukladno tome i upravlja. 
4. Prema tome se prodavaonice poput Bille, Konzuma i Getroa ili specijalizirane prodavaonice poput Lesnine ili Bauhausa nikako ne mogu nazivati trgovačkim centrima.

5. Proces poznat kao blight, a označava smanjenje kvalitete života u središnjim djelovima grada koji se očituje kroz zatvaranje i propadanje trgovina, stambenih i poslovnih objekata te porast delikvencije.

6. Budući je pregled razvoja maloprodaje u Hrvatskoj već bio tema radova pojedinih autora (Lukić, 2002.) mi se ovdje nećemo ponovno njime baviti već ćemo samo u najkraćim crtama prikazati razvoj trgovačkih centara.

7. U središtu Zagreba nalaze se Importanne centar, Rotonda centar, Importanne Galleria, Kaptol centar i Branimir centar. Improtanne centar i Rotonda centar su trgovački centri, Importanne Galleria je trgovačko - stambeno - poslovni centar, a Kaptol centar je trgovačko - poslovni centar. Centri u rubnim djelovima grada te na križanju prometnica su Mercatone, Mercator i King Cross. Sva tri centra su isključivo trgovački centri.

8. Moguće je izdvojiti četiri lokacije (Lukić, 2002):

1. trgovački centri uz cestovna čvorišta na rubovima grada i u gradu

2. trgovački centri uz industrijsku zonu

3. trgovački centri u stambenim zonama

4. središnji poslovni centri

9. Zbog smještaja brojnih prodajnih prostora danas Žitnjak sve više poprima funkciju maloprodajne zone

10. Na Zagrebačkoj je obilaznici moguće izdvojiti četiri čvorišta: Ivanja Reka, Buzin, Lučko i Jankomir

11. posebne autobusne linije postoje za Mercatone i King Cross

12. Takva poslovna politika poznata je kao “one-stop shopping” (Anić 1999.)

13. Prema terenskom kartiranju provedenom u Centru Kaptol u strukturi Centra prema broju lokala određene namijene trgovina na malo je činila $79,1 \%$ svih lokala, no prema površini trgovina na malo je činila svega $50 \%$, a čak $10 \%$ je činio 1 kino kompleks s 3 dvorane. (Lukić, 2002)

14. Trgovački centri se često shvaćaju kao mjesta koja su svima dostupna, no to je samo privid. Trgovački centri su kako u zemljama Zapadne Europe i Sjeverne Amerike, tako i u Zagrebu pod nadzorom službe osiguranja koja sprječava ulaz "nepoželjnima" te se na taj način dobiva važna iluzija sigurnosti.

15. Za razliku od centara na rubu grada te uz glavne prometnice u gradu u Centru Kaptol je primjećena promijena funkcija Centra tijekom dana. U dnevnom prosjeku trgovina je pojedinačno glavni razlog dolaska u Centar, no od jutra prema večeri raste udio posjetitelja koji u Centar dolaze radi zabave i druženje s prijateljima. Taj udio raste od 30,3\% u jutarnjim satima na $50 \%$ u večernjim satima. (Lukić, 2002.)

\section{LITERATURA}

1. Anić I.D., 1998: Razvojni trendovi i problemi maloprodaje u razvijenim zemljama, Ekonomski pregled 49 (9-10), $994-1009$

2. Anić I.D., 1999: Razvitak hrvatske maloprodaje i ekonomsko okruženje, Ekonomski pregled 53 (9 - 10), $883-902$

3. Crewe L., 2000: Geographies of retailing and consumption, Progress in Human geography 24 (2), 275 $-290$

4. Davies W.K.D., Baxter T., 1997: Commercial intensification: the transformation of a highway - oriented ribbon, Geoforum 28 (2), 237 - 252

5. Gerhard U., 2001: Shopping and Leisure: New patterns of consumer behaviour in Canada and Germany, Die Erde 132, 205 - 220 
6. Goss J., 1993: The Magic of the Mall: An analysis of Form, Function and Meaning in the Contemporary Retail Built Enviroment, Annals of the Association of American Geographers, 83 (1), 18 - 47

7. Gregson N., 1995: And now it's all consumption?, Progress in Human Geography 19 (1), 135 - 141

8. Guy C., 1994: Whatever happend to Regional Shopping Centers?, Geography 79, 293 - 312

9. Hallsworth A.G., 1994: Decentralization of Retailing in Britain: The Breaking of the Third Wave, The Profesional Geographer 46 (3), 296 - 307

10. Hallsworth A.G., 1997: Rethinking retail Theory: Circuits of Power as an Integrative Paradigm, Geographical Analysis, 29 (4), 328 - 338

11. Holbrook B., Jackson P., 1996: The social milieux of two north London shopping centres, Geoforum, 27 (2), $193-204$

12. International Council of Shopping Centers Research, http://www.icsc.org

13. Jürgens U., 1997: Retail Trade: Consumer structures in Eastern Germany and response on the supply side, Die Erde 128, 191 - 204

14. Kovačević A., 2002: Ljubljanska avenija u Zagrebu: primjer preobrazbe gradske prometnice, Hrvatski geografski glasnik, 64, 95 - 105

15. Lukić A., 2002: Socijalne funkcije trgovačko - poslovnog središta: primjer Centra Kaptol u Zagrebu, Hrvatski geografski glasnik, 64, 73 - 94

16. Pacione M., 2001: Urban geography, a global perspective, Routledge, London

17. Pütz R., 1997: New business formation, privatisation and internationalisation: aspects of the transformation of Polish retail trade, Wroclaw a case study, Die Erde, 128, 235 - 249

18. Sić M., 1997: Autoceste i lokacija ekonomskih djelatnosti u Središnjoj Hrvatskoj, Hrvatski geografski glasnik, 59, $83-94$

19. Standl H., 1998: Der postsozialistische Transformationsprozess in grossstadtischen Einzelhandel Ostmittel und Osteuropas, Europa Regional, 3, 2 - 15

20. Vresk M., 2002: Grad i urbanizacija. Osnove urbane geografije, Školska knjiga

\section{SUMMARY}

\section{Shopping Centres in Zagreb}

\section{Martina Jakovčić, Dubravka Spevec}

Retail is one of the most resilient and important city functions, and it has had an important role in rise, development and formation of towns. In the course of time retail has gone through vast changes; adapting to the requests and needs of ever growing population - changing the size of outlets, their location, way of retail, and all that in accordance with changes in spatial distribution of population and rise of standard and mobility.

This article deals with the shopping centres in Zagreb. The article does not deal with the shopping centres in the city centre since they have already been the topic of several geographical paper. Appearance and functions of the shopping centres in the city centre 
greatly differ from those located in the outskirts, near traffic junctions and along the main boulevards.

The aim of the article is to present the pattern of development of the shopping centres in Zagreb. The article shows the spatial distribution of the shopping centres and hypermarkets, their commercial structure and function. The data about the commercial structure of the shopping centres were obtained by using the method of observation and mapping of commercial functions in each shopping centre. A survey was done in order to obtain information about functions of shopping centres and ways in which visitors perceive their role in public life. The data were obtained by surveying 1159 visitors in three shopping centres Mercator, Mercatone and King Cross between 02 and 20 December 2003 (three days a week during three weeks).

The first shopping centre in Zagreb was the Importanne Centar on Starčević square (at the Main Railway Station) in the city centre, opened in 1994, and in 1999, the first shopping centre was opened in the outskirts of Zagreb (although the first hypermarket was opened in the year 1994, in the city's eastern outskirts). Since then the number of shopping centres and hypermarkets has grown sharply. Opening of the large number of shopping centres and hypermarkets raises the question of gravitation influence of certain retail outlets. The survey done in all above mentioned shopping centres has shown that almost 92 per cent of visitors live either in Zagreb or in the Zagreb County (Chart.1.)

The majority of visitors, or more precisely 86 per cent of them come to the centre by their own car. Almost equal number of visitors use public means of transportation $(6.7 \%)$ and visit centres on foot (6.6\%). A number of visitors who use the possibility of coming to the centres by special bus lines can be neglected. Numbers of visitors greatly vary among three shopping centres.

In general shopping centres have two main functions: retail and social functions. Shopping centres in Western Europe and Northern America offer visitors the possibility of one - stop shopping. That type of policy attracts visitors to the centre and enables them to save time. In order to undertake such policy shopping centres have to develop different social functions and services. The survey carried out in all three shopping centres has shown that they do not fulfil conditions for undertaking such policy.

In order to research the development of shopping centres' functions we asked visitors about their reasons for coming to the shopping mall, if they visited any of the services and who they visited the centre with. For 46.2 per cent of visitors the main reason for their visit was either shopping or big offer of goods. For only 1.99 per cent of visitors the main reason for their arrival was socialising with friends. 3.89 per cent of visitors came to shopping centre because of a good offer of additional and catering services. This last result shows the growth of services in the shopping centres and in time spent there.

During the working day there are no bigger variations in the reasons for coming to the shopping centres. The results show almost an exclusive orientation of shopping centres to only one function - retail (Table 4.). The shopping centres in the outskirts of Zagreb and by the main traffic junctions still have more developed retail function, while social functions are more or less underdeveloped. The fact that 41.58 per cent of visitors came to the centre alone only confirms the above stated conclusion (Table 5.). 
Although the managements of the shopping centres are trying to make their outlets more appealing to the visitors, the accent in their working policy is still on the development of the retail function. Such conclusions have also been confirmed in the interview with a manager of one of the reviewed shopping centres, where he stated that the main determinant was further development of goods' offer and development of retail functions.

Primljeno (Received): 25 - 3 - 2004

Prihvaćeno (Accepted): 14 - 6 - 2004

Martina Jakovčić, asistent Geografski odsjek, Prirodoslovno - matematički fakultet Marulićev trg 19, Zagreb, Hrvatska / Croatia e-mail: mjakovci@geog.pmf.hr

Dubravka Spevec, prof. geografije

Bernarda Vukasa 43

Zagreb, Hrvatska / Croatia

e-mail: dubravka.spevec@zg.htnet.hr 
